Warto tu też podkreślić, że Autor starając się dokładnie przepisać charakterystyczne skróty stosowane w rękopisach, wykorzystał znaki „wymyślone” przez komputer, nie wykluczając na przykład liter pochodzących nawet $z$ alfabetu arabskiego, by w ten sposób dokładnie oddać graficznie skróty napotkane w badanych kodeksach; omawiana książka jawi się przez to jako ciekawy i nowy „eksperyment” komputerowego zapisu starożytnych autografów.

Ojciec Degórski kończy swe dzieło życzeniem, aby przyczyniło się ono „do coraz lepszego wyboru wariantów, by móc ustalić tekst oryginalny Hieronimowego dzieła", które wcześniej opracował i wydał krytycznie. Z naszej strony możemy żywić nadzieję, iż tego rodzaju rzadkie i cenne badania przyczynią się do rozwoju dalszych poszukiwań zarówno w tej materii, jak i w innych podobnych dziedzinach naukowych, wspierając przy tym również dyscypliny teologiczne.

Luciana Maria Mirri - Bolonia

\title{
Miriam S. TAYLOR, Anti-Judaism and Early Christian Identity. A Critique of the Scholary Consensus, Studia Post-Biblica 46, Leiden - New York - Köln 1995, E. J. Brill, ss. 208.
}

W 1948 roku miało miejsce ważne wydarzenie w środowisku badaczy zajmujących się problemem chrześcijańskiego antyjudaizmu. W tym bowiem roku ukazała się książka Marcela Simona pt. „Verus Israel”. Étude sur les relations entre chrétiens et Juifs dans l'Empire Romain (135-425) (Paris 1948; przekład angielski, Oxford 1986) i można bez przesady powiedzieć, że narzuciła ona nowy sposób patrzenia na przyczyny istnienia tego zjawiska. Zawarte w niej tezy były wyzwaniem dla modelu stworzonego na przełomie wieków przez Adolfa von Harnacka, według którego wrogość chrześcijan wobec Żydów miała podłoże teologiczne. Zgodnie bowiem z założeniami Harnacka chrześcijaństwo cechowała wrodzona wyższość, a jego wzrost odbywał się kosztem judaizmu. W historii kościelnej był on traktowany jako religia zmierzająca ku upadkowi, której los miał coraz mniejsze znaczenie dla wyznawców nowej religii. Opisywany był on przy tym językiem nie stroniącym od przygany i protekcjonalizmu (s. 2). To uzależnienie od teologii zaczęło $\mathrm{z}$ czasem razić tych, którzy pragnęli obiektywnego i krytycznego ujęcia historycznego. Według Simona to właśnie judaizm przez pierwsze wieki naszej ery był liczącą się siłą i w żaden dostrzegalny sposób nie był słabszy od swego rywala. Antyjudaizm, w tej perspektywie, posiada wiele źródeł i przejawów, gdzie współczesna i rzeczywista rywalizacja między chrześcijaństwem i religią Żydów o dominację odgrywa główną rolę. Autorka omawianej przez nas książki określiła tą koncepcję mianem teorii konfliktu (,conflict theory”) i postanowiła poddać 
ją gruntownej krytyce, by na końcu przedstawić własny pogląd na istotę wrogości w stosunku do judaizmu.

Jak przystało na pracę o charakterze metodologicznym jej układ jest usystematyzowany, w tym przypadku jej konstrukcja opiera się na „typologiach”, zgrupowanych w czterech rozdziałach (I. Competitive anti-Judaism, s. 7-45; II. Conflictual anti-Judaism, s. 47-114; III. Inherited anti-Judaism, s. 115-125; IV. Symbolic anti-Judaism, s. 127-187). Mają one ułatwić klasyfikację poglądów naukowych odnośnie przyczyn i przejawów chrześcijańskiego antyjudaizmu. Tego typu budowa książki znacząco ułatwia orientację w analizowanych poglądach badaczy, nawet za cenę dostrzegalnej niekiedy sztuczności. Daje się również wyczuć, że praca podzielona jest na dwie obszerne części, z których pierwszą można określić jako krytykę wspomnianej teorii konfliktu (rozdziały I-III). W drugiej zaś części czytelnik ma okazję zapoznać się z właściwym, zdaniem autorki, obliczem wrogości chrześcijan wobec Żydów.

W części krytycznej podważane są przekonania związane z rywalizacją żydowsko-chrześcijańską, która miała mieć odzwierciedlenie w konkretnych wydarzeniach. Przede wszystkim, zdaniem Simona i jego zwolenników ( np. Robert L. Wilken, John G. Gager), jedna i druga strona dążyła do pozyskania jak największej liczby prozelitów. Jednak źródła, które poświadczałyby wprost misjonarskie dążenia Żydów, są nad wyraz skąpe w porównaniu z wyciąganymi $\mathrm{z}$ nich wnioskami. $\mathrm{Z}$ drugiej strony przejście na judaizm mogło bardziej wskazywać na sympatie i skłonności niektórych pogan, niż na akcje oraz intencje samych Izraelitów. Nawet istnienie licznych „,converts” nie oznaczało jeszcze samo przez się, że podejmowano systematyczne działania dla ich zdobycia (zob. np. M. Goodman, Proselytizing in Rabinic Judaism, ,Journal of Jewish Studies" 38:1987, s. 181). Ponadto traktowanie judaizmu jako religii misyjnej oznacza podporządkowanie jej koncepcji właściwej chrześcijaństwu. Jednak pomimo wagi tych argumentów daleko jest do jednoznacznego rozstrzygnięcia tego problemu. Wydaje się, że istotę problemu oddaje rozbieżność stanowisk w kręgach rabinicznych. Prozelici z jednej strony byli traktowani z nieufnością i podejrzliwością (por. B. Yebam. 47b, 109b; Qidd. 70b; Nid. 13b), z drugiej zaś witano ich niemal z entuzjazmem (por. B. Pesah. 87b; t. Hor. 2:7).

Innym przejawem resentymentów wobec Żydów był tzw. „defensywny antyjudaizm" (Typologia I 2: Defensive anti-Judaism, s. 26-40), opierający się na założeniu, że wśród wyznawców nowej religii były popularne zapożyczenia niektórych żydowskich praktyk religijnych (judeochrześcijanie). Często dochodziło do potępienia ,,judaizowania”, a niechęć, która z tego wynikała, była czymś na kształt reakcji obronnej na wpływy, które zagrażały integralności Kościoła (s. 26). Autorka jest jednak skłonna widzieć słowa potępienia tej praktyki dopiero w pismach z IV i V wieku, czyli poza obszarem swych dociekań. Tymczasem bardziej prawdopodobne jest, że właśnie najsilniej były one obecne wtedy, kiedy granice pomiędzy starą i nową religią nie były jeszcze tak 
wyraźnie zaakcentowane, a samo chrześcijaństwo dopiero kształtowało swe oblicze.

Podważana „teoria konfliktu” prezentuje także szerzej rozpostartą panoramę, na której mają ujawniać się wzajemne animozje. Chodzi tutaj o społeczno-polityczną rywalizację wczesnego chrześcijaństwa i judaizmu wewnątrz rzymskiego państwa. Na podstawie dosyć skąpych zasobów źródeł badacze pragną określić relacje sił pomiędzy tymi dwoma religiami i wyciągnąć wnioski, co do napięć, jakie wynikały z tego powodu. Zakłada się, że Żydzi oraz ich religia byli uprzywilejowani względem wierzących w Chrystusa. Ta dychotomia przedstawia się rzeczywiście dramatycznie: gdy pierwsi cieszyli się statusem religio licita, wpływami i bogactwem, to drudzy byli prześladowani i ubodzy. To musiało według Simona prowadzić do wzbogacenia się wachlarza sposobów wyrażania negatywnych uczuć w stosunku do potężnej synagogi (s. 48). Rozdział, który omawia to zagadnienie (II. Conflictual anti-Judaism, s. 47-114) zawiera kilka ich typologii.

Reactive Anti-Judaism (Typologia II 1, s. 52-74) przedstawia sytuację, kiedy brak równowagi sił oraz względne społeczne upośledzenie Kościoła vis-à-vis żydowskiej wspólnoty miały kreować wrogie reakcje (s. 52) (por. Typologia II 2: Strategic anti-Judaism, s. 75-77). Ta teoria zdaje się znajdować poparcie w odkryciu imponującej synagogi w Sardes w Azji Mniejszej, gdzie, jak się przyjmuje za głównym jej badaczem, A.T. Kraablem, istniała wpływowa i bogata gmina żydowska. Stąd wysnuwa się wniosek, że taka sytuacja musiała budzić w miejscowych chrześcijanach poczucie upokorzenia. W pismach Ojców Kościoła powinny wobec tego znajdować swe ujście odczucia, takie jak „resentyment”, „zazdrość”, czy „irytacja”. Najczęściej badacze powołują się na "jadowicie” antyżydowską Homilię Paschalna Melitona. Jednak zdaniem Taylor, we wzmiankowanym dziele nie ma odbicia współczesnego konfliktu i to z kilku względów. Najpierw wielka synagoga została wybudowana około wiek później po powstaniu tej apologii (ok. 166 r.). W pismach Teofila (II w.), który pochodził z Antiochii, gdzie również od dawna istniała znacząca wspólnota żydowska, brak jest tego typu śladów wrogości. Autorka znacznie silniej niż np. Robert L. Wilken (Melito, the Jewish Community at Sardis, and the Sacrifice of Isaac, ,Theological Studies” 37:1976, 53-69) podkreśla wyłącznie chrystologiczny charakter argumentów Melitona (s. 66), znanego skądinąd z tego, że wymyślił posądzenie Żydów o bogobójstwo (por. s. $72 \mathrm{nn}$.). Jednak czytelnik, który nie do końca chciałby zgodzić się ze zdaniem Taylor, mógłby całkiem bezpiecznie zauważyć, że zanim powstała wspomniana synagoga istniała już dużo wcześniej w tym małoazjatyckim mieście znacząca wspólnota żydowska. Według ustaleń Pietera van der Horsta, (Jews and Christians in Aphrodisias in the Light of their Relations in other Cities of Asia Minor,w: Essays on the Jewish World of Early Christianity, Freiburg 1990, s. 166 n.) miasta tego regionu zamieszkiwało ok. milion Żydów. 
Antyjudaizm, przejawiający się we wzajemnym obwinianiu się (Typologia II 3, Recriminatory anti-Judaism, s. 78-114), miał wynikać z istnienia rywalizacji rozciągniętej na sferę polityki: Żydzi i Rzymianie zawarli alians dla zwalczania wspólnego wroga (s. 93). Związane jest $\mathrm{z}$ tym szeroko rozpowszechnione przekonanie, iż ci pierwsi byli tak nieprzyjaźnie nastawieni wobec wierzących w Chrystusa, że inspirowali i brali udział w ich prześladowaniach. Stąd też m.in. miała wyrastać w stosunku do nich uzasadniona wrogość. Powyższa koncepcja, zdaniem Taylor, ma wiele słabych stron. Przede wszystkim brak jest zupełnie źródeł, które poświadczałyby opisywaną współpracę. Trudno jest również natrafić w okresie między panowaniem Hadriana i Konstantyna na dokumenty wskazujące na żydowską inspirację prześladowań (s. 92). W aktach chrześcijańskich męczenników ich obecność ma za zadanie raczej w jak najpełniejszy sposób upodabniać kaźń danego męczennika i samego Chrystusa (np. męczeństwo Polikarpa, s. 102 nn.). Badacze, którzy uzasadniają obecność inspiracji i pomocy Żydów w nękaniu wyznawców nowej religii, ulegają więc obrazowi o charakterze teologicznym, który wykreowali kościelni pisarze (s. 114). Wydaje się, że można zgodzić się z autorką, ponieważ w posądzeniu Żydów o prześladowania chrześcijan istotnie wiele jest z legendy, która między innymi tworzyła jeden z filarów antyżydowskich (lub, jeśli ktoś chce, antysemickich) uprzedzeń w późniejszych czasach. Swoiście pojęta rola Żydów w męce i śmierci Chrystusa oraz planach Bożych skłaniała do poszukiwania wszechobecności żydowskiej inspiracji w cierpieniach chrześcijan. Imitatio Christi było zresztą bardzo pociągającą ideą przez całe wieki.

Osobną kategorię uprzedzeń stanowią te, które zostały „odziedziczone” przez tych chrześcijan, którzy wyrośli w świecie pogańskim. Tego zagadnienia dotyczy rozdział III: Inherited anti-Judaism (s. 115-125). Wiadomo, że istniała tam bogata skala odczuć, w tym negatywnych, wobec czcicieli Jahwe. Autorka stara się wszakże podkreślić odmienności w tej kwestii pomiędzy obiema społecznościami, bowiem w jednej z nich wielką rolę odgrywały argumenty chrystologiczne. Jednak w omawianym okresie zachodził już proces adaptacji dorobku antyku do potrzeb religii chrześcijańskiej. Po roku 70 zaznacza się także wzrost liczby pogan w szeregach nowej wiary, którzy jak można się domyślić, wzbogacali wymiar wrogości w stosunku do Żydów.

Krytyka dotychczasowych koncepcji, dotyczących chrześcijańskiego antyjudaizmu, skłoniła autorkę do zajęcia własnego punktu widzenia na omawiany problem. W rozdziale IV Symbolic anti-Judaism (s. 127-187) prezentowana jest dyskusja nad teologicznym wymiarem antypatii wobec Żydów (Typologia IV 1, s. 127-169). Przyjmuje się najczęściej, że był on wynikiem usiłowań Kościoła mających na celu wyjaśnienie sprzeczności powstałych z jednoczesnego przejęcia żydowskiego Boga i Biblii oraz odrzucenia Prawa, które obwieścił ten sam Bóg w tym Piśmie (s. 127). Różnie próbowano to uzasadnić: Żydzi nie rozumieli Pisma i stąd je utracili, odrzucając Chrystusa odrzucili tym samym swą 
tradycję, dawne Prawo zaś było niedoskonałe wobec nowego. Idąc tym tropem, na co już wcześniej zwracała uwagę Taylor, należy odrzucić wieloprzyczynowy model wyjaśniający, i skoncentrować się na tym, co jest głównym zagadnieniem w pismach Ojców Kościoła, tj. na aspekcie teologicznym. Będąc niejako w sferze rozważań abstrakcyjnych, można zatem rozpatrywać obraz Żydów i tego, co jest z nimi związane, jako swego rodzaju „historycznie transmitowane symbole" (przydatna okazała się tutaj koncepcja antropologa Clifforda Geertza, zgodnie z którą kultura to seria symboli lub „odziedziczonych koncepcji w symbolicznej formie, za pomocą których ludzie komunikują, uwieczniają i rozwijają swoją wiedzę o życiu i stosunek doń" (Religion as a Cultural System, w: M. Barton, [ed.] Anthropological approaches to the Study of Religion, London 1966, s. 3). Za ich pomocą wczesnochrześcijańscy pisarze starali się „przekazywać, uwieczniać i rozwijać” swe odmienne (distinctive) koncepcje świata (s. 159). Żydzi jawią się tam jako przeciwieństwo chrześcijan. Zajmowali oni negatywną stronę w dialektycznym dualizmie dobra i zła (wspólnoty i jej wrogów), który jest tak właściwy myśli wyrosłej z Nowego Testamentu (s. 166).

Mianem symbolicznego antyjudaizmu można również określić wypowiedzi zawarte w pismach przeciwko gnostykowi Marcjonowi, który starał się odrzucić żydowskie dziedzictwo (Typologia IV 2: Reaffirmative anti-Judaism, s. 170175). Jego poglądy podważały sens przejęcia Boga, zapowiedzianego Mesjasza i Biblii od Żydów. Jak pisze Taylor: „,własne piętno antyjudaizmu było oczywiście istotne w tym przedsięwzięciu, jednak antyżydowskie argumenty były ponownie redagowane (restated) coraz bardziej gwałtownie przeciw Marcjonowi, by na przykład, udowodnić, że to nie Bóg, ale raczej ludzie Starego Testamentu byli zmienni i niegodni (fickle and unworthy). Anytsemityzm użyty przeciw temu autorowi i jego zwolennikom można więc nazwać ,potwierdzającym”, ponieważ kształtował on integralną część „potwierdzenia”, via media w obliczu zagrożenia, jakim była herezja Marcjona, która mogła zupełnie oderwać Kościół od jego żydowskich korzeni” (s. 171).

Bez wątpienia na własny użytek „stosowano” antyżydowskie motywy jeszcze w dwóch przypadkach, określonych wspólnym mianem ,ilustracyjnego antyjudaizmu” (Typologia IV 3, s. 176-187). Wykreowano go, aby „wzmocnił strukturę moralną swych współwyznawców przez krzewienie cnót oraz poprzez egzorty do nieugiętości w praktykach chrześcijańskich" (zob. Tertulian, De patientia, 5, 22-25; Cyprian, De bono patientiae, 7, 19, s. 178). Przykłady słabości i grzeszności Izraela miały zatem charakter ilustracyjny, a nie polemiczny (s. 181). Jest to tzw. „pokrzepiający antyjudaizm” (fortifying anti-judaism). Do walki z oponentami w łonie Kościoła służył jego wariant, który można określić mianem „skojarzeniowego” (associative) lub „retorycznego”. Jego obecność dostrzega się u Tertuliana, gdy łączy on swych oponentów z judaizmem, dzięki czemu może wykazać „słabość” ich stanowiska (zob. Tertulian, Adversus Praxean, 31, 1-2; De monogamia, 7, 1; s. 181 nn.). 
Czytelnik, który zgłębi pracę Miriam S. Taylor, ma okazję zapoznać się $\mathrm{z}$ umiejętnie przeprowadzoną krytyką dominującego paradygmatu badawczego, zwanego „teorią konfliktu”. Należy przyznać, że zastrzeżenia poczynione przez autorkę skłaniają, aby o wiele ostrożniej spoglądać na dostępne nam źródła i to jest istotna zasługa tej pracy. Te z nich bowiem, które nie mają charakteru patrystycznego, w nikły sposób rozpraszają mrok spowijający wzajemne relacje chrześcijańsko-żydowskie, a wnioski, jakie się z nich wyciąga, mogą prowadzić na manowce. Pisma Ojców Kościoła zaś poświęcone były problemom natury teologicznej, choć trzeba przyznać, że niekiedy powstawały one pod wpływem bieżących wydarzeń (np. herezja Marcjona). (Autorka dodałaby jednak, że odzwierciedlały one ponadczasowe idee oraz odporne na ząb czasu „historycznie transmitowane symbole”). Dzieła Tertuliana czy Melitona były wobec tego nie tyle reakcją na otaczającą rzeczywistość, ile odzwierciedleniem świata wyobrażeń religijnych obecnych wewnątrz chrześcijańskiej gminy. Jednak ten antyjudaizm, choć będący odpowiedzią na wewnętrzne potrzeby, w jakiś sposób kształtował późniejsze poczynania cesarzy, mnichów, a może i pospólstwa. Szkoda więc, że autorka nie próbuje dać odpowiedzi co do zależności, jakie mogły zachodzić pomiędzy abstrakcyjnym antyjudaizmem Ojców Kościoła, a wrogimi wystąpieniami z czasów tryumfu chrześcijaństwa. Wydaje się, że byłoby słusznym zabiegiem, gdyby w analizowanych źródłach literackich dostrzegać zarówno wpływy „symbolicznego antyjudaizmu”, za którym opowiada się autorka oraz bieżącej sytuacji. Powstaje dzięki temu obraz pełniejszy i pozbawiony suchej jednostronności. W innym przypadku trudno pozbyć się wątpliwości, czy model wieloprzyczynowy, odwołujący się do „tu i teraz” nie został zastąpiony przez monolityczną strukturę, implikującą brak wzajemnych kontaktów co najmniej od czasów apostolskich.

Wojciech Bejda - Lublin

\section{Jeffrey Paul LYON, Syriac Gospel Translations: A Comparison of the Lan- guage and Diatessaron Method used in the Old Syriac, the Diatessaron and the Peshitto, CSCO 548, Subsidia 88, Louvain 1994, ss. 235.}

Książka J. P. Lyona jest owocem kilkuletnich studiów na uniwersytetach amerykańskich w Kaliformii między innymi u prof. Stanisława Segerta. Jak słusznie zauważył Lyon, chociaż przed 90-ciu laty wydano teksty ewangelii starosyryjskich (versio curetoniana i sinaitica), to nie przeprowadzono studiów porównawczych między podstawowym tekstem Peszitty a versio curetoniana i sinaitica. Rozprawa Loyna wychodzi naprzeciw temu postulatowi, kiedy stawia sobie za cel przebadanie języka i metody przekładu stosowanych w versio curetoniana, sinaitica, Diatessaronie i Peszitcie. 